\title{
Dissociation Constants for Carbonic Anhydrase-Sulfonamide Binding by High-Performance Liquid Chromatography
}

\author{
William R. A. OSBORne AND Richard E. TASHIAN* \\ Department of Pediatrics, RD-20. University of W'ashingtom, Seatle, Washington 98195, and "Department of \\ Human Genetics, University of Michigan Medical School, Ann Arhor. Michigan 48109
}

Received May 24, 1983

\begin{abstract}
Carbonic anliydrase-azosulfonamide dissociation constants $\left(K_{\mathrm{d}}\right)$ were determined by gel filtration with high-performance liquid chromatography. By measuring the area of the elution peak at two wavelengths, $K_{\mathrm{d}}$ values were derived without having to measure a shallow trough. The procedure proved to be fast and reliable and has a general application. The dissociation constants were measured for 7-acetamido-2-(4'-sulfamylphenylazo)-1-hydroxynaphthalene-3,6-disulfonate (Neoprontosil) complexes with carbonic anhydrase isozymes CA I, CA II, and CA III from bovine and human sources, and chicken $\mathrm{CA}$ III from skeletal muscle.

KEY WORDS: carbonic anhydrase: sulfonamides; dissociation constant; gel filtration.
\end{abstract}

Carbonic anhydrase (CA) (EC 4.2.1.1) is present in mammals as at least three isozymes, $\mathrm{C} \wedge \mathrm{I}, \mathrm{C} \wedge \mathrm{II}$, and $\mathrm{C} \wedge$ III, whose structural genes appear to have evolved by gene duplications before the divergence of the land vertebrates, i.e., reptiles, birds, and mammals (1). These isozymes are monomeric, zinc metalloenzymes $\left(M_{\mathrm{r}} 29,000\right)$ which catalyze the reversible hydration of $\mathrm{CO}_{2}(2,3)$; the CA II isozymes have the highest turnover numbers, followed in order by the CA I and CA III isozymes $(4,5)$. Aromatic and heterocyclic sulfonamides (e.g., sulfanilamide, acetazolamide) are known to be specific inhibitors of the CA isozymes; however, the affinities of the different $\mathrm{C} \Lambda$ isozymes for the sulfonamide inhibitors vary with the particular isozyme and type of sulfonamide (5-7). Most sulfonamides are strong inhibitors of the mammalian CA II isozymes and usually have lower affinities for the CA I isozymes, but are only weakly bound to the CA III isozymes (5). Crystallographic studies of the binding of sulfonamides

'Abbreviations used: CA, carbonic anhydrase; CA I, CA II, and CA III, carbonic anhydrases I. II, and III; SDS, sodium dodecyl sulfate. in the active sites of human CA I and CA II have revealed two important features: (a) the sulfonamide group $\left(-\mathrm{SO}_{2} \mathrm{NH}_{2}\right)$ is firmly liganded, with little mobility, to the zinc ion replacing the solvent ligand $\left(\mathrm{OH}^{-}\right.$or $\left.\mathrm{H}_{2} \mathrm{O}\right)$ normally present at the fourth ligand site, and (b) the aromatic or heterocyclic ring structures appear to interact with certain residues in the hydrophobic part of the active site cavities $(3,7)$.

In studies involving the kinetics of $\mathrm{CA}$-sulfonamide binding, it is often important to be able to accurately determine the dissociation constant $\left(K_{d}\right)$ of a CA-inhibitor complex. For instance, $K_{d}$ values for azosulfonamide binding were required for studies on the proteolytic degradation of the CA isozymes (8). Carbonic anhydrase activities are routinely measured using synthetic esters, often of limited water solubility and stability to hydrolysis. Also, no assay is optimal for all three isozymes as CA I and CA II have maximal activities for ester hydrolysis and $\mathrm{CO}_{2}$ hydration, respectively, whereas CA III is a relatively poor catalyst for both reactions $(2,3)$. Therefore, employing a gel-filtration procedure (9-12), we developed a method to obtain values for carbonic an- 
hydrase-inhibitor binding. By recording chromatograms at two different wavelengths it was possible to determine dissociation constants without the need to measure the area of a flat trough. This was of particular benefit at low levels of inhibitor binding where very shallow negative areas are obtained which are difficult to estimate. This method has a general application. and it is especially useful for ligands which have absorption bands at wavelengths $>340 \mathrm{~nm}$.

\section{EXPERIMENTAL PROCEDURES}

Reagents. Neoprontosil (7-acetamido-2-(4'sulfamylphenylazo) - 1 - hydroxynaphthalene 3,6-disulfonate) was obtained from Winthrop Laboratories, New York, and Sephadex G25 superfine from Pharmacia. All other reagents were from Sigma.

Enzyme purification. Human CA I, human CA II. and bovine CA II were purified from hemolysates, and bovine CA I was from rumen by column chromatography on sulfonamidebound affinity columns (13). Human CA III was prepared from skeletal muscle extracts by affinity chromatography (13), eluted with a 0 to $0.2 \mathrm{M} \mathrm{KI}$ gradient in $0.005 \mathrm{M}$ Tris- $\mathrm{SO}_{4}$ buffer, $\mathrm{pH}$ 8.7. and further purified by chromatography on Sephadex G-75 (14). Bovine and chicken CA III, which bind only very weakly to the sulfonamide column, were separated from the sulfonamide-bound $\mathrm{CA} I$ and CA II isozymes by first passing the muscle extracts through an affinity column (13). followed by chromatography on DEAE-cellulose with further purification on Sephadex G-75. Carbonic an hydrase activity was measured by an esterase assay using $p$-nitrophenyl acetate (15). The purified enzymes gave a single band upon SDS-gel electrophoresis (16).

Difference spectra. The azosulfonamide difference spectra were determined as described (15) and were recorded as free inhibitor against enzyme-inhibitor complex. For Neoprontosil the millimolar extinction coefficients $\left(\mathrm{mM}^{-1}\right.$ $\mathrm{cm}^{-1}$ ) were 15.3 at $280 \mathrm{~nm}, 10.3$ at $370 \mathrm{~nm}$, and 11.4 at $380 \mathrm{~nm}$ at $\mathrm{pH} 8.0$. Molar extinc- tion coefficients $\left(\mathrm{M}^{-1} \mathrm{~cm}^{-1}\right)$ used for the CA isozymes were human CA I, $47.3 \times 10^{3}(15)$; human CA II, $54.0 \times 10^{3}(15)$; human $\mathrm{CA}$ III, $63.8 \times 10^{3}(17)$; bovine CA I, $51.0 \times 10^{3}$ (18); bovine CA II, $57.0 \times 10^{3}(19)$; bovine CA III, $56.6 \times 10^{3}(5)$; and chicken CA III, $59.1 \times 10^{3}(20)$.

Gel-filtration chromatography. Glass columns $0.4 \mathrm{~cm}$ i.d. by $20 \mathrm{~cm}$ or $12 \mathrm{~cm}$ in length were packed with Sephadex G25 superfine. For the liquid chromatography a Waters instrument was used, equipped with a Schoeffel variable-wavelength detector, a Spectra Physics integrator, and a Texas Instruments chart recorder. The column was equilibrated in 25 $\mathrm{mM}$ Tris- $\mathrm{HCl}, \mathrm{pH} 8.0$, with or without Neoprontosil $(0.025-15 \mu \mathrm{M})$. Carbonic anhydrase solutions of 5-25 $\mu \mathrm{l}$, equivalent to $5-30 \mu \mathrm{g}$ enzyme protein, were chromatographed at a flow rate of $1 \mathrm{ml} / \mathrm{min}$ and 0.1 to 0.04 fullscale absorbance. For enzyme without inhibitor the detector was set at $280 \mathrm{~nm}$, and for enzyme plus azosulfonamide a wavelength of 370 or $380 \mathrm{~nm}$ was used, corresponding to zero absorbance difference between free and bound inhibitor.

Calculation of dissociation constant. The dissociation constant was given by the equation $K_{d}=E_{\mathrm{f}} I_{\mathrm{f}} / E I$, where $E_{\mathrm{f}}$ and $I_{\mathrm{f}}$ were the concentrations of free enzyme and inhibitor, respectively, and $E I$ was the concentration of enzyme-inhibitor complex which was equal to bound enzyme $E_{\mathrm{b}}$, or bound inhibitor $I_{\mathrm{b}}$. The dissociation constant can be calculated from peak areas. The peak area obtained at $280 \mathrm{~nm}$ when enzyme alone was chromatographed was equivalent to total enzyme $E_{\mathrm{t}}$, which equals $E_{\mathrm{b}}+E_{\mathrm{f}}$. The enzyme was rechromatographed in the presence of inhibitor and the peak area was recorded at the second wavelength ( 370 or $380 \mathrm{~nm}$ ). This area was equivalent to bound inhibitor $I_{\mathrm{b}}$, as there was no contribution from enzyme protein. From the extinction coefficients at the two wavelengths, this area was calculated as the area equivalent to bound enzyme $E_{\mathrm{b}}$ at $280 \mathrm{~mm}$, and the area of free enzyme $E_{\mathrm{f}}$ obtained by subtraction from $E_{\mathrm{t}}$. The concentration of the 
free inhibitor was known and the dissociation constant was given by $K_{t}=I_{\mathrm{f}}$ (peak area $E_{\mathrm{f}}$ ) peak area $E_{\mathrm{b}}$ ). This calculation was facilitated by the use of an inhibitor absorbing in the visible spectrum. However, if the extinction coefficients of all components are known at any two wavelengths, then $K_{d}$ can be calculated from peak areas obtained from elution profiles of repeat chromatograms with the detector set at the two chosen wavelengths. It was also necessary to determine a difference spectrum to monitor if the free ligand changes its absorption spectrum upon binding to enzyme.

\section{RESULTS AND DISCUSSION}

The azosulfonamide difference spectra of human CA III and chicken CA III (Fig. 1) were similar in profile to those reported for human CA I and CA II (15). The concentra-

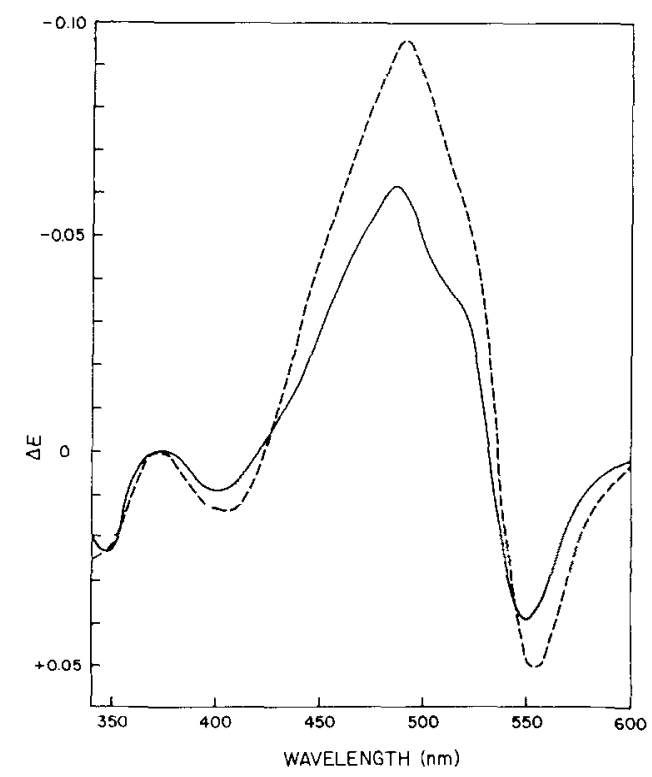

FIG. 1. Difference spectra at pH 8 of the Neoprontosil complexes of human CA III (- - -) and chicken CA III (-). The concentrations of chicken CA III and human CA III were 9 and $10 \mu \mathrm{M}$, respectively, and that of Neoprontosil was $50 \mu \mathrm{M}$. The negative sign indicates a decrease in absorbance of enzyme-inhibitor complex relative to free inhibitor. The spectra were recorded at $22^{\circ} \mathrm{C}$ and the buffer was $25 \mathrm{~mm}$ Tris- $\mathrm{HCl}$, pH 8.0 . tion of chicken CA III was $9 \mu \mathrm{M}$ and that of human CA III was $10 \mu \mathrm{M}$, both with $50 \mu \mathrm{M}$ Neoprontosil which gave $<3 \% E_{\mathrm{f}}$. The spectra were recorded at $22^{\circ} \mathrm{C}$. The negative sign indicates a decrease in absorbance of enzymeinhibitor complex relative to free inhibitor. Both CA III enzymes showed a maximum negative absorbance between 485 and $490 \mathrm{~nm}$, and peaks of positive sign at 400 and $550 \mathrm{~nm}$. The chicken CA III also showed a positive peak at $350 \mathrm{~nm}$. The change in millimolar extinction coefficient for inhibitor complexes at $490 \mathrm{~nm}$ for human CA III. chicken CA III, and bovine CA III were 8.8, 6.7, and 10.0 $\mathrm{mM}^{-1} \mathrm{~cm}^{-1}$, respectively. The value for human CA III is between the values for human CA I and CA II previously reported (15). At wavelengths between 370 and $380 \mathrm{~nm}$ there was no change in sulfonamide absorbance following binding to the various enzymes. The zero absorbance change was at $380 \mathrm{~nm}$ for bovine CA I and CA II and human CA II. and at 370 $\mathrm{nm}$ for the other enzymes. The elution profiles of the enzyme-sulfonamide complexes were recorded at the wavelengths giving zero absorbance difference.

The elution profile of human CA I recorded at $370 \mathrm{~nm}$ after chromatography in buffer plus $1 \mu \mathrm{M}$ azosulfonamide showed a sharp symmetrical peak with retention time of $150 \mathrm{~s}$ (Fig. 2). This peak represented the inhibitor bound to the enzyme, and the trough eluting at $18 \mathrm{~min}$ was also equivalent to this, as it represents the inhibitor removed from the equilibrated buffer solution as the enzyme migrated down the column. The column used in this chromatogram was $20 \mathrm{~cm}$ long and allowed repeat chromatograms at 25-min intervals. This time was nearly halved using a column of $12 \mathrm{~cm}$ length. During these analyses, the maximum pressure registered at the pump was 400 psi. For the time that the enzyme was within the chromatographic system $(<150 \mathrm{~s})$, there was no evidence of denaturation as monitored by esterase assay. The columns were durable and were used for at least 50 runs without the generation of artifacts due to gel compressibility. 


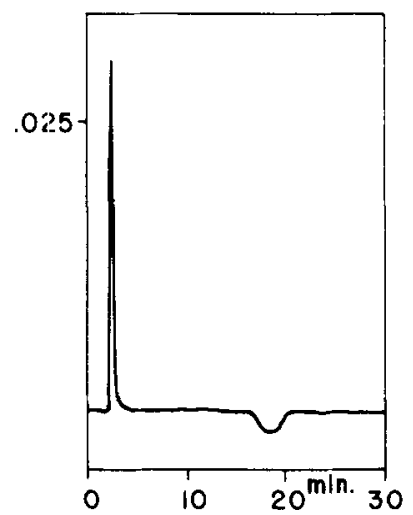

FIG. 2. Elution profile of human CA I-Neoprontosil. The column $(0.4 \times 20 \mathrm{~cm})$ of Sephadex $\mathrm{G} 25$ (superfine) was equilibrated with $25 \mathrm{~mm}$ Tris-HCl. $\mathrm{pH} 8$.0, containing $1 \mu \mathrm{M}$ Neoprontosil. The enzyme was dissolved in the solution and $20 \mu \mathrm{g}$ in $10 \mu \mathrm{l}$ was chromatographed at a flow rate of $1 \mathrm{ml} / \mathrm{m}$ in and $22^{\circ} \mathrm{C}$. The ordinate represents absorbance at $370 \mathrm{~nm}$.

The inhibitor binding to human CA I at various free inhibitor concentrations was determined and plotted in the form suggested by Klotz (21) (Fig. 3). That is, $E_{\mathrm{t}} / I_{\mathrm{b}}=K_{d} / n I_{\mathrm{f}}$ $+1 / n$, where $n$ is the number of ligand molecules bound per mole of enzyme. The ordinate was derived from the peak areas for enzyme chromatographed with buffer alone $\left(E_{\mathrm{t}}\right)$ and from enzyme with inhibitor concentrations of 0.025 to $1 \mu \mathrm{M}$ to give $I_{\mathrm{b}}$. At these inhibitor concentrations the proportion of complexed enzyme varied from 20 to $90 \%$. From the slope and intercept $K_{d}$ is $0.10 \mu \mathrm{M}$ and $n$ is 1 . Figure 3 shows this method can be applied to a range of inhibitor concentrations. However, inhibitor levels giving $>90 \%$ $E I$ gave less reproducible results.

The dissociation constants were determined for the various carbonic anhydrases at two or more different inhibitor concentrations at $22^{\circ} \mathrm{C}$ (Table 1). No difference was observed in $K_{d}$ values obtained for human CA II when the protein concentration was varied from 0.3 to $1.5 \mathrm{mg} / \mathrm{ml}$ at constant inhibitor level. This indicates that, over this fivefold concentration range, protein-ligand intera-*ion is not dependent on enzyme level $(11,12)$. The tendency for the mammalian CA isozymes to bind sulfonamides in the order CA II $>\mathrm{CA}$ I > CA III was generally reflected in their respective $K_{d}$ values (Table 1). The reasons for (a) the similar $K_{d l}$ values for bovine CA I and CA II, (b) the differences in the $K_{d}$ values between human and bovine CA III, and (c) the relatively low $K_{d}$ value for chicken CA III (similar to human CA I) were not evident by examining their respective active site residues (1). Although the amino acid sequences for human and chicken CA III isozymes are still incomplete, no differences have as yet been observed for any of the residues postulated to occur in the active sites of the bovine, human. and chicken CA III isozymes (1). The relatively high affinity of chicken CA III for Neoprontosil was not in agreement with the data of Holmes (20), who showed (using an esterase assay) that $1 \mathrm{mM}$ acetazolamide was required to completely inhibit this isozyme. The $K_{d}$ values for human CA I and CA II are in general agreement with $I_{50}$ values for acetazolamide inhibition determined using a $\mathrm{CO}_{2}$-hydratase assay (5).

This adaptation of the gel-filtration method of Hummel and Dryer (9) involves the measurement of only sharp elution peaks at two wavelengths and has, by not requiring measurements of shallow negative areas, provided a proccdure for determining dissociation constants that was fast and reliable. and has a general application. It is particularly useful for enzymes such as carbonic anhydrase that

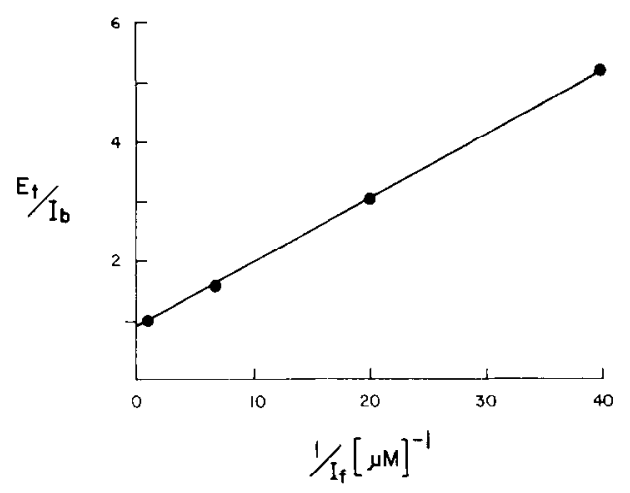

FIG. 3. Klotz plot (21) of Neoprontosil binding to human CA I. 
TABLE 1

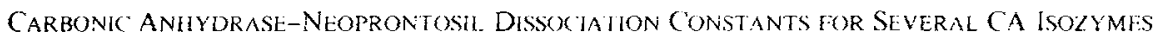

\begin{tabular}{lcrr}
\hline & & $K_{d}(\mu \mathrm{M})^{a}$ & \\
\cline { 2 - 4 } & CA & CA II & CA III \\
\hline Human & $0.102 \pm 0.013(4)^{h}$ & $0.027 \pm 0.003(6)$ & $1.400 \pm 0.251(9)$ \\
Bovine & $0.056 \pm 0.010(4)$ & $0.064 \pm 0.007(6)$ & $18.900 \pm 2.503(4)$ \\
Chicken & - & - & $0.110 \pm 0.010(6)$ \\
\hline
\end{tabular}

${ }^{a}$ Mean \pm standard deviation.

${ }^{h}$ Number of determinations.

are not conveniently assayed. Furthermore, it does not require the use of radiolabeled ligands and can be accomplished with microgram quantities of enzyme protein. It requires only the analysis of sharp, easily integrated peaks and an accurate knowledge of ligand concentration. A true enzyme inhibitor dissociation constant $K_{d}$ is obtained, to which $K_{i}$ values derived from enzyme assays are not necessarily equivalent.

\section{ACKNOWLEDGMENTS}

We thank Dr. David Hewett-Emmett and Rosalind J. Welty for preparing the human CA III samples. and YaShiou L. Yu for preparing samples of the other CA isozymes. This work was supported by United States Public Health Service Grants Al-12617, GM 15253, and GM 24681 (to R.E.T.), and the National Foundation.

\section{REFERENCES}

1. Tashian, R. E., Hewett-Emmett. D.. and Goodman. M. (1983) in Isozymes: Current Topics in Biomed1cal and Medical Research (Kattazzi, M. C., Scandalios, J. G., and Whitt, G. S., eds.), Vol. 7, pp. 79-100, A. R. Liss, New York.

2. Pocker, Y., and Sarkanen, S. L. (1978) Advan. Enzymol. 47, 149-274.

3. Lindskog, S. (1982) in Advances in Inorganic Biochemistry (Eichhorn, G. L., and Marzilli. L. G., eds.). Vol. 4, pp. 115-170. Elsevier, Amsterdam/ New York.

4. Koester, M. K., Pullan. L. M.. and Noltman. E. A. (1981) Arch. Biochem. Biophys. 211, 632-642.
5. Sanyal, G., Swenson, E. R., Pessah, N. I., and Maren, T. H. (1982) Mol. Pharmacol. 22, 211-220.

6. Whitney, P. L., Folsch, G., Nyman. P. O., and Malmstrom, B. G. (1967) J. Biol. Chem. 242, 42064211 .

7. Kannan, K. K., Vaara, I., Notstrand, B., Lovgren. S., Borell, A., Fridborg. K., and Petef. M. (1977) in Drug Action at the Molecular Level (Roberts, G. C. K., ed.), pp. 73-91, Univ. Park Press, Baltimore.

8. Osborne, W. R. A, and Tashian RE (1981) J. Biol. Chem. 256, 1330-1334.

9. Hummel, J, P., and Dreyer, W. J. (1962) Biochim. Biophys. Acta 63, 530-532.

10. Cuatrescasas, P.. Fuchs, S., and Antinsen, C. B. (1967) J. Biol. Chem. 242, 3063-3067.

11. Parsons, D. L. (1980) J. Chromatogr. 193, 520-521.

12. Sebille, B., Thaud, N., and Tillement, J. P. (1980) J. Chromalogr. 193, 522-523.

13. Osborne, W. R. A., and Tashian, R. E. (1975) Anal. Biochem. 64, 297-303.

14. Hewett-Emmetl, D., Welty, R. J., and Tashian, R. E. (1983) Genetics 105, 409-420.

15. Osborne, W. R. A. and Tashian, R. E. (1974) Biohem. I. 141, 219-225.

16. Osborne, W. R. A. (1980) J. Biol. Chem. 255, 70897092 .

17. Carter, N.. Jeffery, S., Shiels. A.. Edwards, Y., Tipler. T., and Hopkinson. D. A. (1979) Biochem. Genet. 17, 837-854.

18. Carter, M. J. (1971) Biochim. Biophys. Acta 235, 222236.

19. Nyman. P-O., and Lindskog. S. (1964) Biochim. Biophys. Acta 85, 141-151.

20. Holmes, R. S. (1977) Eur. J. Biochem. 78, 511-520.

21. Klotz, I. M., Walker, F. M., and Pivan, R. B. (1946) J. Amer. Chem. Soc. 68, 1486-1490. 